кандидат педагогічних наук, доцент

(Житомирський державний університет імені Івана Франка) helen.maks23@ukr. net

ORCID: 0000-0003-1590-4339

\title{
ВИХОВАННЯ МІЖОСОБИСТІСНОЇ ТОЛЕРАНТНОСТІ У ДІТЕЙ ЗАСОБАМИ КАЗОК В. СУХОМЛИНСЬКОГО
}

Стаття присвячена проблемі морального виховання, зокрема такому ї̈ аспекту, як толерантність. Аналізується змістова наповнюваність означеної категорії, під якою розуміється властивість особистості, щзо проявляється у здатності до поваги, розуміння, визнання та прийняття іншої людини, у ціннісному ставленні до багатого різноманіття культур нашого світу, форм самовираження людини $i$ способів прояву індивідуальності. Розкривається виховний потенціал казки у формуванні основ світогляду та поведінки дитини. Аналізується зміст казок В. Сухомлинського з точки зору їх впливу на формування ознак толерантної особистості.

Ключові слова: моральне виховання, толерантність, терпимість, повага прав іншого, визнання суб' єктності іншого, казка.

Постановка проблеми у загальному вигляді та іï зв'язок із важливими науковими i практичними завданнями. Проблема морального виховання у сьогоденні стоїть особливо гостро, оскільки розмаїття цінностей, часте переважання матеріального над духовним нівелюють неписані закони моралі, підштовхуючи людей до асоціальних дій заради власної вигоди. Іноді нерозуміння іншого, заперечення його прав на свободу, насаджування своєї позиції призводить до фатальних наслідків, втягуючи у криваві війни держави, народи. Наразі виховання терпимої позиції до інакшості оточуючих та поціновування життя і здоров'я як свого, так і будь-якого представника роду людського, веде до збереження миру на Землі та рівноваги і спокою всередині власного "Я". Таким чином, толерантність як особистісна риса набуває питомої ваги і стає бажаною для всіх.

Аналіз основних досліджень і публікацій із зазначеної проблеми. Останнім часом дана проблема розглядалась багатьма вченими. Зокрема, як основну цінність суспільства, толерантність розглядали А. Асмолов, І. Бех, Є. Головаха, Є. Зєлєнов, І. Зязюн, В. Пухляк, Г. Солдатова, Л. Хоружа. Історичний контекст розвитку проблеми толерантності відображено у працях вітчизняних і зарубіжних науковців (П. Бейль, І. Вишенський, Ф.-М. Вольтер, К.-А. Гельвецій, І. Гізель, М. Грушевський, М. Драгоманов, В. Липинський, Дж. Локк, Дж. Мілль, Ш.-Л де Монтеск'є, Т. Мор). Теоретико-методологічному обгрунтуванню поняття "толерантність" присвячені дослідження філософів (Л. Буєва, О. Грива, Ю. Іщенко, С. Касьянова, М. Конш, О. Садохін, Л. Скворцов, В. Соловйов, А. Шопенгауер), політологів та правознавців (М. Гаджимірзаєв, М. Гулієв, С. Маркова, М. Монастирська, О. Стогова, Г. Олінченко, В. Ханстантинов), етнополітологів та етнографів (К. Леві-Стросс, Г. Рамазан), соціологів (С. Головаха, Л. Дробіжева, Л. Завірюха, Р. Інглхарт, В. Лекторський, М. Шимановський), психологів (О. Асмолов, I. Бех, Н. Буравльова, Г. Бюзелева, Г. Олпорт, Е. Фром, Г. Шелемова), педагогів (О. Безкоровайна, Б. Гершунський, В. Глебкін, С. Зеленов, Е. Музенітова, С. Степанов).

Окреслення невирішених питань, порушених у статті. Попри значний інтерес науковців до проблеми толерантності у наш час, їх увага не зосереджувалась на можливостях авторських казок В. Сухомлинського як засобу формування толерантної особистості.

Формулювання завдань статті. Завданням нашої статті $\epsilon$ аналіз доробку видатного вченого В. Сухомлинського у вигляді казок 3 точки зору його використання - як засобу виховання міжособистісної толерантності у дітей.

Виклад основного матеріалу 3 обгрунтуванням отриманих наукових результатів. Спершу з’ясуємо змістову наповнюваність категорії "толерантність". Складність цієї дефініції полягає в багатьох відтінках іiі значення, які обумовлені національними особливостями різних народів, їх історичним минулим. Історично поняття "толерантність" бере свій початок 3 епохи релігійних воєн і виражає компроміс, на який повинні були піти католики та протестанти після того, як стало зрозуміло, що жодна сторона не отримає остаточної повної перемоги. У вікіпедії толерантність (від лат. tolerantia - терпіння) означається як ослаблення чи відсутність можливості реакції на який-небудь несприятливий фактор в результаті зниження чутливості до його впливу. Також відмічається, що на індивідуальному рівні - це здатність сприймати без агресії думки, які відрізняються від власних, особливості поведінки та способу життя інших. Тут же зустрічаємо міркування, що терпимість до чужого способу життя, поведінки, звичаїв, почуттів, дей, вірувань є умовою стабільності та єдності суспільств, особливо тих, які не $є$ гомогенними ні у релігійному, ні в етнічному, ні в інших соціальних вимірах. 
Толерантність віддзеркалює інтуїтивне сприйняття єдності людства, взаємозалежності всіх від кожного і навпаки, і складається 3 поваги прав іншого, в тому числі права бути іншим, а також в утриманні від скоєння шкоди, оскільки шкода, що завдається іншому, є шкодою для всіх і для самого себе (ця ідея яскраво змальована у давньоассірійській легенді "Ассірійський цар Асархадон"). В ідеалі, толерантність захищає свободу кожного, забезпечуючи право діяти в межах не забороненого, водночас позначаючи межі, за якими починається свобода інших. В основі толерантного ставлення лежить визнання суб'єктності іншого, свободи вибору та права на реалізацію власних інтересів.

Отже, толерантність передбачає повагу і визнання рівності, відмову від домінування та насилля, визнання багатогранності людської культури, норм, вірувань; відмову від зведення цього розмаїття до однаковості чи переваги якоїсь однієї точки зору. Кожна особистість має право на свою думку, свої цінності, свої інтереси, які повинна відстоювати і захищати, але при цьому 3 повагою ставитись до позицій та цінностей інших. Резюмуючи різні підходи до визначення суті категорії "толерантність", означаємо іiї як властивість особистості, що проявляється в здатності до поваги, розуміння, визнання та прийняття іншої людини, іiї позиції щодо соціальних, політичних, релігійних тощо поглядів, у ціннісному ставленні до багатого різноманіття культур нашого світу, форм самовираження людини і способів прояву індивідуальності.

Виховуючи толерантність у підростаючого покоління, доречно звернутись до такого могутнього засобу, як казка. Загалом вона має величезний виховний потенціал, є гарним помічником у формуванні основ спілкування і поведінки. Казка розвиває дитячу особистість, особливо мовлення та уяву, знімає страхи і тривоги. Вона ненав'язливо і доступно розкриває перед малечею мораль нашого суспільства, вводить у світ взаємин і ставлень до однолітків, до молодших та старших людей, формує систему цінностей. 3 казкових героїв діти беруть приклад, їх хочуть наслідувати, обирають ідеалом, на який прагнуть бути схожим. Казка дітям набагато цікавіша і дієвіша за нудні промови і повчання дорослих. Безсумнівна користь від казки і в позитивних емоціях малюка, який ії слухає. Казка часто стає реальним сценарієм у житті людини, і не тільки в дитячі роки, а і у дорослому житті. Під іiі впливом формуються лінії поведінки в реальному світі.

В. О. Сухомлинський був серед дітей щодня. Він жив їх життям, переживав разом 3 ними приємні і болісні моменти їх долі, бачив жагу знань в очах, будив допитливість, підштовхував до мрій. Добре вивчивши дитячу душу, педагог знав, чим зацікавити, як пояснити, як навчити правильно себе поводити. Наймогутнішим засобом вважав казку, писав їх сам, стимулював до написання учнів, вимагав і від свого педагогічного колективу творчого казкоскладання.

Матеріалом для казки виступала навколишня дійсність. Гостра спостережливість педагога і уміння помічати дрібнички давали поштовх творчому початку нових і нових казок. Кожна з них розширювала світогляд дітей, вчила добру і милосердю, викликала особливе, уважне ставлення до природи, жагу до знань, змушувала замислитись. Моральність педагога через казку передавалась і дітям. Ненав'язливо, у цікавій формі формувався моральний світогляд і ціннісна сфера малюків.

Потенціал дитячої казки, написаної В. О. Сухомлинським, використовується вихователями, вчителями у сьогоденні. Надзвичайно багатий матеріал можна знайти і щодо формування засад міжособистісної толерантності у дітей. Проаналізуємо деякі казки великого педагога. "Добре слово" розкриває могутність і чарівну силу слова. Смачні наїдки і гостинці, вітаміни і корисні продукти, які приносили хворій дівчинці родичі, не допомагали. А лагідне слово зробило диво, змусило хворобу відступити, підняло ii на ноги. Немає нічого, щоб коштувало так дешево і цінувалось так дорого, як добре слово. "Соловей і Жук" демонструє рівноцінність і право на життя усього живого на Землі. Відповідно і навчає дітей ставитись уважно і шанобливо до іншого. Соловей, який вважав себе кращим за Жука, а свій спів чарівним, нетерпляче поставився до гудіння жука. А Жук дав йому мудру відповідь про свою необхідність. Звернулись до дівчинки, яка підтвердила особливість і самоцінність кожного 3 них. Казка навчає терпляче і з розумінням сприймати іншого, проявляючи повагу і визнаючи його право на життя.

Казка "Дідусь і смерть" навчає дітей чинити добро для людей, залишати по собі добрі справи. Смерть (як уособлення зла), яка прийшла за Дідусем, подарувала йому три дні життя, які він попросив. Та й цікаво їй стало, що ж за ці дні зробить Дідусь. А він почав садити дерева, щоб людям добро зробити. Злякалась того Смерть та й втекла від Дідуся. Отже, доля повертається до тих, хто робить гарні справи не задля своєї вигоди чи очікуючи винагороди, а безкорисно. Добро і толерантність - як два боки однієї медалі.

Глибока думка потреби Людини в іншому закладена у казці "Дівчинка і Ромашка". Ромашка була обдурена каменем, який їй пообіцяв захист від вітру, дощу, спеки і холоду, коли вона була маленьким насіннячком і шукала тепле місце. Але як тільки з'явилось у Квітки власне бажання і потреба побачити сонечко, камінь їі майже розчавив. Бажання бачити тільки себе і володарювати над Ромашкою ледь не знищило квітку. Врятувала Дівчинка. I Ромашка попросилася належати їй. Сама по собі квітка бути не могла. Вона наводила Дівчинці приклади того, що кожна квітка комусь належить. Наодинці вона б 
померла від туги. Так і в людей: життя приносить насолоду, якщо живеш задля когось, а не тільки для себе. Весело і щасливо тоді, коли поруч з тобою той, хто бажає тобі добра, намагається зробити для тебе приємність, потурбуватися. Тоді і віддати хочеться сторицею. Але так чинити може тільки той, хто поважає іншого, не ставить себе на вищий щабель, а зважає на потреби і почуття тих, хто поруч.

Байдужість засуджується у казці "Байдужий пеньок". Головний герой - пеньок - був старим, мохом обрісшим, тільки грівся собі на сонечку, очі замруживши. Ніщо його вже не хвилювало, не засмучувало і не робило радісним. Пропозицію дружити Пеньок прийняв і від Їжака, і від Гадюки. А коли вони зчепились між собою, то Пеньок не втрутився, не допоміг. I навіть дізнавшись про наслідки сутички (загибель Гадюки, з якою погодився дружити), ніяк не відреагував, закрив очі та й далі грівся на сонечку. Байдужий не може бути товаришем. Тільки той, в кого багата палітра почуттів, може забути про себе заради іншого, простягнути руку помочі, розрадити і пожаліти.

Зворушує душу казка "А серце тобі нічого не наказало?" У Андрійка в сім'ї сталась біда: татко занедужав, та поклали його до лікарні. Материні заплакані очі ніяк не здивували сина. Вона, бачачи нечутливість Андрійка, сказала йому про горе. А Андрійко у відповідь не висловив ні хвилювання за батька, ні занепокоєння, ні співчуття. Він турбувався про свій завтрашній похід до лісу з класом. Боляче матері було дивитись на черствість сина. Якщо вже рідний батько байдужий своєму синові, то що казати і про інших. Не виросте з такого хлопчика гарної Людини. Не зможе він побачити нікого, крім себе. А такі люди нікому не милі.

Протилежні Андрійкові постаті змальовані у казці "Бабусин борщ". Дві онучки приїхали до старенької бабусі на гостини. Радо вона частувала їх городиною. Та дівчаткам хотілося спробувати бабусиного борщу. Бабуся швиденько взялась за справу, наварила смачного борщику, та тільки біда зі старістю прийшла: забувати стала, то й посолила двічі. Та ще й на стіл солонку поставила, попередивши дівчаток, що не пам'ятає, чи посолила страву. Дівчата радо взялись за борщ, а він солоний-пресолоний. Та ображати бабусю, яка для них так старалась, не хотіли. Тому й вигляду не подали. Все з’їли й похвалили. Дівчата поціновували старання бабусі, iї бажання їм догодити, і з розумінням поставились до іiї віку та забудькуватості. Не образили бабусю люблячі онучки. Ця ж ідея покладена педагогом і у казку "Чому мама так хвалить". Тільки у ній уже, навпаки, зображене толерантне і любляче ставлення матусі до своєї донечки, яка хотіла порадувати свою неньку, що прийде з роботи стомлена і голодна, а тому наварила борщу, хоч мама про це і не просила. Та тільки біда - борщ у маленької шестирічної Людмили вийшов несмачний. Спробувала його дівчинка і засмутилась. А мама прийшла з роботи, з’їла всю тарілку і так хвалила донечку! Іноді потрібно оцінювати не результат, а мотив, який підштовхнув дитину до діяльності. І заохочувати добрі наміри та вчинки.

Про силу усмішки розповідає однойменна казка. Іноді і слів не потрібно, досить лише погляду та виразу обличчя, щоб вплинути на настрій іншого, його стан і почуття. Дівчинка йшла полем у погожий день. Їй все подобалось, і все звеселяло. Та раптом побачила похмурого і злого дідуся, який ішов назустріч. Спробувала його "заразити" своєю посмішкою, але невдало. I наповнилося дитяче серце страхом та сумом, і все навкруги здалося сірим, безбарвним. Врятувала від цього стану старенька бабуся, яка трапилася на шляху. Боязко подивилася на неї життєрадісна дівчинка, і побачила жаданий лагідний погляд і усмішку. Так легко подарувати радість ближньому, і нічого це не варто. Застерігає казка від нав’язування своїх поганих почуттів, настрою комусь. Думай про оточуючих - посміхайся.

Навчає толерантному ставленню казка "Горбатенька дівчинка". До класу директор привів нову ученицю. Була вона калікою. Діти бувають часто жорстокими. Тому застиг учитель перед учнями, благаючи їх лише очима не виявити до горбатенької дівчинки чи то подиву, чи то насмішки. Та клас витримав екзамен на гідність. Привітне ставлення і лише цікавість як до нової учениці прокотилися класом. Усі люди різні. І ставитись до іншого з розумінням, на рівних, без образ за його особливість чи відмінність навчити буває нелегко.

Вчить ставитися по-доброму до людей з особливими потребами і казка "Як Сергійко навчився жаліти". Хлопчик грався біля ставка і зустрів там сліпу дівчинку, яка слухала шум хвильок. Сергійка так здивувало нещастя дівчинки, що він весь день про це думав. А вночі прокинувся від вітру і дощу, який стукав у шибки. Було темно і страшно. І знову хлопчик подумав про сліпу дівчинку, адже живе вона у суцільній темряві постійно. Як же ій має бути страшно. Так шкода стало дівчинку! Серце хлопчика стискав жаль. I подумав Сергійко, що завтра знову піде до ставка, щоб побачитись з дівчинкою, тільки вже не буде дивуватись, а пожаліє іiі.

Казка "Розділена радість" виховує у дітей уміння увійти у світ почуттів іншого, його переживань i психічних станів. У Катрусі сталась велика радість: їі татко після трьох операцій і року хвороби нарешті видужав. I понесла дівчинка своє щастя до друзів, подружок. Але ніхто 3 них не зміг зрозуміти Катрусиного захвату, ніхто не хотів розділити з нею щастя. I весела посмішка змінилася сльозами розчарування. I лише однокласник Костя нарешті зумів порадіти разом із дівчинкою. Його душа виявилась спроможною зрозуміти і розділити щастя Катрусі. I знову засяяли очі дівчинки, і радість теплом розлилась по всьому тілу. 
Ряд казок В. О. Сухомлинський присвятив повчанню дітей правильно ставитись до членів своєї родини. "Образливе слово" розповідає про хлопчика, який згарячу сказав своїй матусі погане слово. I мучила його совість за той вчинок. Виріс хлопчик. Та й настав час йому їхати в далекі краї. Просить син вибачення у матері за те слово. Материнська душа любляча прощає все, але сльози давньої образи і душевного болю покотилися по щоках матері. Не може забути мама тих слів. Душевний біль іноді гірше фізичного.

Пробуджує тепло в душі казка "Найгарніша мама". Немає нікого милішого і красивішого ні в людини, ні у тварини від рідної неньки. Випало маленьке совеня з гнізда та й не мого віднайти свого гніздечка. Зібрались пташки біля нього і стали розпитувати. А совеня й відповідає, що його мама - найгарніша, схожа на нього. Стали пташки сміятись і глузувати. А совеня захищає свою матусю, відстоює думку, що вона - найкраща. На той крик прилетіла сова і побачила своє дитинча. Взяла його за лапку та й повела додому. А совеня уважно дивилося на маму і знало, що вона - найгарніша.

А казка "Іменинний обід" наскрізь просякнута ідеєю виховання толерантного ставлення у дітей до старшого покоління. Дівчинка Ніна засоромилася своєї бабусі, у якої руки тремтіли, і на свій День народження попросила, щоб мама не садила бабусю за стіл, адже прийдуть подруги і побачать тремтячі руки бабусі. Мама вчинила мудро: вона зняла білу святкову скатертину і сказала, що святкового обіду не буде, тому що бабуся захворіла. Так з дитячих років закладається повага і терпимість до старості, адже це неодмінно чекає на кожного, якщо пощастить дожити. Старість не повинна викликати сорому. Матуся побажала доньці бути справжньою людиною!

Продовжує ідею поважного ставлення до старості казка "Комірчина для дідуся". Не по-людськи повів себе тато Юрка, вирішивши старенького хворого дідуся переселити з хати в комірчину. I незіпсована душа маленького хлопчика відгукнулась на таку несправедливість. Пішов копати він землянку на майбутнє для своїх батьків, провівши паралель: як батьки ставляться до своїх батьків, так і їх діти в майбутньому вчинять із ними.

Висновки та перспективи подальшого дослідження проблеми. Таким чином, казка в руках умілого педагога може направити на правильний шлях дитячу душу, свідомість, визначити ії ставлення до оточуючих, виховати толерантною, дбайливою і чуйною. Результатом виховання дітей засобом казки $€$ такі цінні особистісні якості, як повага до іншого, вміння зважати на його думку, доброта, емпатійність, бажання допомогти іншому. Подальші напрямки дослідження з даної проблематики вбачаємо у розкритті інструментарію роботи вихователя 3 прищеплення міжособистісної толерантності дітям; наступності 3 формування толерантної особистості дошкільника та молодшого школяра; спільної роботи педагога 3 батьками з навчання толерантному ставленню дитини до ближнього.

\section{СПИСОК ВИКОРИСТАНИХ ДЖЕРЕЛ ТА ЛІТЕРАТУРИ}

1. Казки Василя Сухомлинського [Електронний ресурс]. - Режим доступу: http://derevokazok.com.ua/category/tales/avtor-ukr/казки-василя-сухомлинського.

2. Максимова О. О. Ідея толерантності у гуманітарних науках / О. О. Максимова // Наукові записки : [збірник наукових статей]. - М-во освіти і науки України; Нац. пед. ун-т імені М. П. Драгоманова ; укл. : Л. Л. Макаренко. - К. : Вид-во НПУ імені М. П. Драгоманова, 2014. - Вип. 122. - С. 116-123.

3. Сухомлинський В. О. Я розповім вам казку... Філософія для дітей / Василь Сухомлинський ; уклад. Сухомлинська О. В. - Х. : ВД "Школа", 2016. - 576 с.

\section{REFERENCES (TRANSLATED \& TRANSLITERATED)}

1. Kazky Vasylia Sukhomlyns'koho [Tails of Vasilii Sukhomlinskii] [Elektronnyi resurs]. - Rezhym dostupu: http://derevo-kazok.com.ua/category/tales/avtor-ukr/kazky-vasylya-sukhomlyns'koho.

2. Maksimova O. O. Ideia tolerantnosti u gumanitarnykh naukakh [Idea of Tolerance in Humanities]/ O. O. Maksimova // Naukovi zapiski [Academic Writings] : [zbirnyk naukovykh statei]. - M-vo osvity i nauky Ukraini ; Nats. ped. un-t imeni M. P. Dragomanova; ukl. : L. L. Makarenko. - K. : Vid-vo NPU imeni M. P. Dragomanova, 2014. - Vyp. 122. - S. 116-123.

3. Sukhomlinskii V. O. Ya rozpovim vam kazku... Filosofiia dlia ditei [I'll Tell you a Story... Philosophy for Children] / Vasyl' Sukhomlinskii ; uklad. Sukhomlynska O. V. - H. : VD "Shkola", 2016. - 576 s.

\section{Максимова Е. А. Воспитание межличностной толерантности у детей средствами сказок В. Сухомлинского.}

Статья посвящена проблеме нравственного воспитания, в частности такому ее аспекту, как толерантность. Анализируется содержательная наполняемость обозначенной категории, под которой понимается свойство личности, проявляющееся в способности к уважению, пониманию, признанию и принятию другого человека, в ценностном отношении к богатому многообразию культур нашего мира, форм самовыражения человека и способов проявления индивидуальности. Раскрывается воспитательный потенциал сказки в формировании основ мировоззрения и поведения ребенка. 
Анализируется содержание сказок В. Сухомлинского с точки зрения их влияния на формирование признаков толерантной личности.

Ключевые слова: нравственное воспитание, толерантность, терпимость, уважение прав другого, признание субъектности другого, сказка.

\section{Maksymova O. O. Children's Education of Interpersonal Tolerance by V. Sukhomlynsky's Tales.}

Research deals with finding the best ways to form a tolerant child. The author's tale of $V$. Sukhomlynsky is analysed from this point of view; especially its potential for moral education in general and tolerance as its aspect in particular. Scientific methods of analysis, synthesis, comparison, abstraction were used to select stories, the material of which is appropriate to form tolerance as a personal quality of kids. Speaking about tolerance we mean individual quality, which is shown in the ability to respect, understand, and accept the thoughts and ideas of the other person in social, political, religious spheres; in his tolerant attitude to the rich cultural diversity of our world, forms of self-expression and ways of manifestation of personality.

Unobtrusively a tale creates moral outlook and value sphere of babies. An extremely rich material can be found about forming the foundations of interpersonal tolerance in children. Thus, V. Sukhomlynsky's fairy tale "Good Word" discovers the might and the magic power of words. The tale "Grandpa and Death" teaches children to do good for people to leave a good memory helping everybody. A deep thought that human needs each other is shown in the tale "The Girl and a Daisy." Indifference is condemned in the tales "Indifferent stump" and "Has your heart ordered you nothing?". Tales "Mother's soup" and "Why mother praises so much" teach to value not only results of the work, but also attached diligence, motivation, desire to please somebody, the ability to understand the age difference of people. The tale "A Humpback girl" educates a tolerant attitude in humans, an ability to understand, to be equal, and not to hurt anybody for his difference. A Fairy tale "As Sergei learnt to regret" teaches to treat people with disabilities very kindly.

A fairy tale has a huge educational potential. It broadens the outlook of children, teaches kindness and mercy, a special and careful attention to nature, thirst for knowledge, makes people think.

Key words: moral education, tolerance, respect for the rights of the others, the recognition of subjectivity of others, tale. 